\title{
The Effectiveness of Using Self-Questioning Strategy in Developing Strategic Listening and Self-Regulation
}

\author{
Maraam Alutaybi ${ }^{1^{*}} \quad$ Hamad Alsowat $^{2}$ \\ 1.English Language Centre, Deanship of Supportive Studies, Taif University, PO box 2973, Taif 26575, Saudi \\ Arabia \\ 2.Curricula and Educational Technology, Faculty of Education, Taif University, PO box 6414, Taif 21944, Saudi \\ Arabia
}

\begin{abstract}
The study aimed at investigating the effectiveness of using self-questioning strategy in developing strategic listening and self-regulation of female students at Taif University. It adopted the quasi-experimental design: a pre/ post-test. It incorporated (89). The researcher designed a strategic listening skills test which was based on a list of strategic listening skills prepared by the researcher. Also, a self-regulation scale was used to measure students' self-regulation adapted from (Alsowat, 2013). The most important results of the study were: There were statistically significant differences between the mean scores of the study groups in the post strategic listening skills in favor of the experimental group. Also, there were no statistically significant differences between the mean scores of the study groups in the post self-regulation skills. Finally, there was no statistically significant difference between the mean scores of the experimental group in the post strategic listening skills due to (high-low) selfregulation skills.
\end{abstract}

Keywords: Self-Questioning, English Language, Strategic Listening Skills, Self-Regulation, University Students. DOI: $10.7176 / \mathrm{JEP} / 11-8-17$

Publication date:March $31^{\text {st }} 2020$

\section{Introduction}

English is considered the language most universally used. It is imperative for different aspects of life, such as science, education, technology, business, travelling and much more (Alasmari, 2016). Among the four fundamental language skills, listening is considered as the most important and an essential skill when learning a foreign language (Gilakjani \& Sabouri, 2016). Listening strategies are a part of learning strategies; they are used to enhance the learning process and communication (Goh, Meng \& Kaur, 2013). To become strategic listeners, listeners should have the two components of strategic listening which are the metacognitive components and the regulation component. Metacognitive components are knowing about strategies and how and when to use these strategies. A regulation component uses these strategies, monitoring and evaluating them (Amin et al., 2011). Researchers in the field of ESL listening have concentrated on the importance of learners' metacognitive knowledge in listening (e.g. Aguilera et al., 2016; Movahed, 2014; Zarrabi, 2016) and other studies (e.g. Huy, 2015; Pan, 2015; Zanjani \& Izadpanah, 2016) focused on the effect of strategy use on developing the listening skill. In spite of a wide range of areas investigated in these two components, there has been a lack of research on strategic listening (Amin et al., 2011).

Strategic learners, who acquire learning strategies, use them effectively, plan, monitor and evaluate their learning and have a chance at becoming self-regulated learners (Steiner, 2016). Self-regulated learning is not an academic skill nor a mental ability. It is a process that is directive in nature (Zimmerman, 2002), focuses on the learner's role in the process of learning (Hatami, 2015) which affects students' learning and their achievements, and enhances it according to Bandura's social cognitive theory (Schunk \& Zimmerman, 2007). Many scholars have proposed different models of self-regulation (e.g. McCaslin \& Hickey, 2001; Pintrich, 2000; Zimmerman, 2000). In this study, the researcher has selected the Zimmerman (2000) cyclical model. This model has three phases: the forethought phase, the performance control phase, and the self-reflection phase (Schunk \& Zimmerman, 2007).

During the last five years, self-regulated learning has been examined with a large amount of research focusing on developing a student's academic achievement, proficiency and motivation (e.g. El-Sakka, 2016; LeanahTascilar, 2016; Ebadi \& Shakoorzadeh, 2015). In his research about self-regulated strategy instruction, El-Sakka (2016) concludes that there are four categories of self-regulation strategies which are: cognitive, metacognitive, management and behavioral strategies. By using these strategies, a learner can increase the awareness of his/her learning (Punhagui \& Souza, 2013).

Previous studies have shown that this strategy is a useful tool for students when increasing their reading comprehension such as (Afzali, 2012; Rose, 2014; Rouse, Alber-Morgan, Cullen \& Sawyer, 2014). However, there remains a lack of studies that explore the effectiveness of the self-questioning strategy with the listening skill.

\section{Problem of the Study}

There are many difficulties in listening comprehension skills, especially in strategic listening skills for different 
types of texts. Among learners of English as a second language (ESL), such problems may occur when predicting the main idea, guessing the general meaning, capturing the keywords that convey the main idea, listening to the specific details, writing notes, linking new information to their background and activating prior knowledge (Huy, 2015; Piamsai, 2014; Na \& Yang, 2009). These difficulties can be due to the lack of motivation, low performance, low-level of proficiency, lack of ability, anxiety, distraction, lack of autonomy and responsibility for learning and low-level of listening comprehension (Amin et al., 2011; An \& Shi, 2013; Eslahkonha \& Mall-Amiri, 2014; Kaya, 2017).

Based on the researcher's teaching experience as an English instructor at Taif University in addition to the findings of the pilot study, there are many female university students who lack knowledge of strategic listening skills such as predicting the main idea of the text, guessing its content, linking the text with their prior knowledge and their experience. Some learners lack self-regulation skills such as setting their goals, knowing a large number of learning strategies, knowing how, when and where to use them, responding to the situation, cooperating and collaborating with their classmates, planning, memorizing, monitoring and evaluating their actions (Borkowski \& Thorpe, 1994; Cubukcu, 2009; Khusainova \& Ivutina, 2016; Steiner, 2016). Relatively few strategic listening studies exist involving the Saudi ESL setting and most of the existing studies on L2 listeners use the qualitative research method to investigate listening strategies use and students' metacognitive awareness, but few studies use a quantitative method to collect data.

\section{Literature Review}

\subsection{Self-Questioning Strategy}

Self-questioning is a metacognitive strategy which is significant for both comprehension and acquisition (O'Shea \& Obiakor, 2008). Janseen (2002:99) defined self-questioning as "a specific study strategy designed to enhance students' comprehension and recall of expository texts about specific subject matter". By reviewing literature, this strategy is based on three theories: schema theory, metacognitive theory, and active processing theory. As Janseen (2002) emphasizes, the role of the Schema theory in teaching is to activate the students' background knowledge through self-questioning strategy. Formulating questions associates the incoming information with what is already known (Miciano, 2002) in order to accomplish successful listening comprehension (He, 2016). Self-questioning is considered as a metacognitive strategy which is used to help students monitor their comprehension of the text and increase their knowledge (Livingston, 2003; Shang \& Chang-Chien, 2010, Woolley, 2011). It helps students to monitor their listening comprehension by identifying important information and regulation strategies. Hence, as long as students' metacognition is enhanced, they are able to regulate their own listening process. According to active processing theory, comprehension and generating more and higher-level questions are increased by using self-questioning strategy (Janseen, 2002). The student can actively get involved in the content of the text (Shang, Chang-Chien, 2010). The importance of this strategy lies in the following:

1. Facilitating students' thinking about what they are reading (Rouse, 2014).

2. Powering students become active and engaged learners (Sunggingwati \& Nguyen, 2013).

3. Promoting self-regulations and fosters independent learning while reading (Afzali, 2012).

4. Improving students' comprehension level and enhances their academic grades (Joseph et al., 2016).

5. Increasing students' self-esteem and motivation for learning (Thomas, 2002).

Generating questions is an important method and advanced comprehension skill (Rouse, Alber-Morgan, Cullen \& Sawyer, 2014). Many researchers classified the questions into different categories. Shang and ChangChien (2010) classified questions into memory questions, main-idea questions and higher-order questions. Memory questions are the questions which are different in intentionality level and have an equivalent number of factual recall questions (Stiller \& Dunbar, 2007). Main-idea questions are the questions which ask about the most important thought and topic (Lubliner, 2004). Higher- order questions are questions which stimulate students' thinking more deeply and develop their cognitive skills (Freahat \& Smadi, 2014). Furthermore, Kramarski and Dudai (2009) distinguished four types of questions: comprehension questions, connection questions, strategy questions and reflection questions. Comprehension questions encourage learners to get the information. Connection questions help learners to understand the relational structures more deeply. Strategy questions prompt learners to choose and plan the proper strategy. Reflection questions encourage learners to monitor and evaluate their process.

Studies on the effectiveness of self-questioning strategy are very few. All of them are conducted in a reading context such as Rouse (2014), Rouse, Alber-Morgan, Cullen \& Sawyer (2014), Alsoud (2016), and Alhayajnah \& Altall, (2017). These studies revealed a significant impact of self-questioning strategy in developing reading comprehension. In addition, as the best of the researcher knowledge, this strategy has never been implemented with the students' strategic listening and their self-regulation. This study tries to bridge the gap that arises from the limited studies that attempt to use self-questioning in developing strategic listening, which indicates listening strategy knowledge and use, and self-regulation. 


\subsection{Strategic Listening}

Schwartz (1998) defined strategic listening as the process that listeners:

"are aware of their listening processes, have a repertoire of listening strategies, and know which work best for them, with which listening task, are flexible in their use of strategies and will try a different strategy if the one they originally chose does not work for them, use both bottom-up and top-down strategies, and plan, monitor and evaluate before, during and after listening" (p. 7).

There are two components of strategic listening: the knowledge and the use of listening strategies. When the learners have the knowledge about these strategies and the ability to use them more efficiently, they will be more confident and skillful (Movahed, 2014).

According to Amin et al. (2011), listening strategy knowledge is divided into three types:

1. The first type is declarative knowledge. It means knowing about the strategies and one's repertoire, what and why of listening strategy use.

2. The second type is procedural knowledge. It means knowing how to use listening strategies successfully.

3. The third type is conditional knowledge. It means knowing when and where to use listening strategies.

The second component of strategic listening is listening strategy use. Good EFL/ESL listeners use the strategies when their listening skills fail (Amin et al., 2011). By using them, listeners will be active participants and the listening process is marked as a successful one (Richards, 2008). Strategic listening is important in: a) enhancing learning and without strategy use, the awareness of learning is impossible, b) performing specific language tasks and the selection is based on the nature of the task, and c) solving certain problems when performing the task. It has a positive impact on language learning by making learning easier, faster and enjoyable (Aguilera et al., 2016). Generally, learning strategies are categorized into three types: cognitive strategies, metacognitive strategies and socio-affective strategies. By teaching students how, when and why to use listening strategies, they will have both the skill and the knowledge to use them properly and then become strategic listeners (Amin et al., 2011).

In the view of the previous studies, it has been noted that the current study, as the best of the researcher knowledge, is the first study that designs a list of main and subskills of strategic listening while the study of Amin et al., (2011) examined the relationship between EFL students' listening comprehension skills and their strategic listening. The sample consisted of eighty female high school students randomly chosen at El-Shimaa Secondary School for Girls, Egypt. A Strategic Listening Interview, a Strategic Listening Questionnaire and a Strategic Listening Checklist with think-aloud protocol were used to measure the students' strategic listening while the listening comprehension test was used to measure their listening comprehension skills. Results showed a significant positive correlation between strategic listening and listening comprehension. Most of the existing studies on L2 listeners use qualitative research method to investigate listening strategies use and students' metacognitive awareness but no study uses a quantitative method to collect data. Moreover, the findings of the studies (e.g. An \& Shi's, 2013; Movahed, 2014; Zeng, 2014; Nejad, 2015; Zarrabi's study, 2016) revealed the effectiveness of listening strategy instruction, listening strategy use and metacognitive listening strategy awareness with different learning grades, levels, and genders. Some studies showed a positive relationship between listening comprehension and listening strategy use e.g. Eslahkonha and Mall-Amiri (2014) who conducted a study to explore the correlation between Iranian TEFL learners' listening comprehension and the use of listening strategies. It was evidenced by the study that there was a correlation between the students' listening comprehension ability level and their listening strategy use, and Kassem's study (2015) that determined the listening comprehension strategies used by Egyptian EFL learners when listening to English material more frequently. The findings indicated that students used cognitive strategies more than metacognitive and socio-affective strategies, there was a significant correlation between the use of listening strategy and listening comprehension, and a significant correlation between the use of listening strategy and self-efficacy. In addition, the study of Kaya (2017) investigated the correlation between the use of listening strategies and listening proficiency, and between selfefficacy and listening proficiency. It was found that the students' listening proficiency was significantly correlated with their use of strategies. There was a significant correlation between the students' self-efficacy and their listening proficiency, and no significant correlation between the low proficiency students and their use of listening strategy, and also their self-efficacy. Pan \& In'nami (2015) examined the relationship between strategy use, second language proficiency, test performance in listening assessment, and types of test task. The results showed that the planning, monitoring and evaluation, , bottom-up processing strategies, and elaboration and linguistic inference were used by advanced learners while approaches, voice and imagery inference and elaboration and top-down processing strategies were used by most of the listeners regardless their proficiency level, students used planning strategies in easier tasks, and the correlation between test scores and strategy use was weak. So, then there is a demand to conduct more studies related to strategic listening. 
whereby learners set goals for their learning and then attempt to monitor, regulate, and control their cognition, motivation, and behavior, guided and constrained by their goals and the contextual features in the environment" (Pintrich, 2000: 453). Moreover, Zumbrunn, Tadlock and Roberts (2011: 4) defined it as "a process that assists students in managing their thoughts, behaviors, and emotions in order to successfully navigate their learning experiences". SR is important in increasing student's academic achievement (Montroy, Bowles, Skibbe \& Foster, 2014; Zimmerman, 2008), improving their self-efficacy and self-satisfaction (Zimmerman, 1990; Zimmerman, 2002), fostering their life-long learning skills (Zimmerman, 2002; Zumbrunn, Tadlock \& Roberts, 2011), promoting their academic motivation (Maralani, 2016; Zimmerman, 1990), enhancing their autonomy and allow them to learn independently and responsibly (Oruc \& Arslan, 2016; Miedijensky \& Lichtinger, 2016), and influencing their engagement, performance and success (Lichtinger \& Kaplan, 2011; Zhao, 2016). It promotes different study skills such as speaking proficiency, reading comprehension and writing achievement (El-Sakka, 2016; Schunk \& Zimmerman, 2007).

Many researchers have proposed different models of self-regulation. These models will be presented as the following:

3.3.1 Zimmerman's Social-Cognitive Model.

In this model, there are three cyclical phases: 1) forethought phase, 2) performance phase, and 3) self-reflection phase. These phases are discussed in brief.

1. Forethought phase:

This phase refers to a process and beliefs that precede learning. In this phase, students are proactive agents. They are analyzing the task, setting their goals, engaging in strategic planning, modeling, and assessing their selfefficacy beliefs, intrinsic interest, goal orientation, and outcome expectations.

2. Performance phase:

This phase refers to a process and beliefs that occur during learning. It facilitates self-control and self-observation of students' performance. Students employ strategies to attain their own goals and monitor the effectiveness of these strategies and their motivation. They use some techniques such as imagery, self-instruction, help seeking and environmental structuring in order to direct learning.

3. Self-reflection phase:

This phase refers to a process and beliefs that occur after learning. It influences students future planning and goals. Students in this phase evaluate their performance and the outcomes of their learning, examine the level of their satisfaction with the task completion, determine whether there is a need for changes in strategies, and compare their performances with their goals. Then, the third phase (self-reflection), in turn, impact the first phase (forethought) during future learning to complete a self-regulatory cycle (Bembenutty, 2011; Zimmerman, 2002; Zimmerman, 2013).

3.3.2 Pintrich (2000) Model.

In this model, there are four phases: 1) Planning, 2) Self-monitoring, 3) Control, and 4) Evaluation. These four phases depict a general sequence that students during learning.

1. Planning phase.

Students are setting specific goals and objectives, activating their prior knowledge, recognizing the difficulties in the tasks, and activating their motivational beliefs and emotions.

2. Self-monitoring phase:

Students are aware of their state of motivation, emotions and cognition. They are also aware of time and effort they use, the conditions of the task and their behavior.

3. Control phase:

Students choose and use thought strategies such as cognitive and metacognitive strategies, motivational and emotional strategies and the strategies that are related to control the structure and atmosphere of the class, and academic tasks.

4. Evaluation phase:

Students evaluate and judge the task achievement and compare it with some criteria. According to the causes of successes or failures, attributions are made. Then, there is a general assessment at the end about the task and the class environment (Eissa, 2015; Fermin \& Maria, 2010).

In view of previous studies, it is clear that most of them revealed the effectiveness of self-regulated learning with different learning levels. The samples were high school students, university students and students with learning disability. The results of some studies confirmed the effectiveness of self-regulated learning on improving reading comprehension such as Eissa (2015) and speaking proficiency e.g. El-Sakka (2016). Abbasian and Hartoonian's study (2014) showed a positive relationship between language proficiency and self-regulated learning strategies. There was also a strong relationship between students' self-regulation and their language learning strategies in Erdogan's study (2017). In addition, there was a positive correlation between students' self-efficacy and their online self-regulation in the study of Su, Zheng, Liang and Tsai (2018). On the other hand, some research had uncertain findings of the relationship between self-regulated learning strategies and foreign language 
classroom anxiety such as Martirossian and Hartoonian (2015) and between self-regulated learning and the prediction of students' GPA e.g. Çetin (2015). The current study resembles Author (2015) in investigating the effectiveness of using a strategy to improve students' self-regulation.

\section{Questions of the Study}

This study tends to answer the following major question:

What is the effectiveness of using self-questioning strategy (SQS) in developing strategic listening and selfregulation of female students at Taif university?

This question was divided into the following sub-questions:

1. What is the effectiveness of using self-questioning strategy (SQS) in developing strategic listening of female students at Taif university?

2. What is the effectiveness of using self-questioning strategy (SQS) in developing self-regulation of female students at Taif university?

3. Is there any statistically significant difference between the mean scores of the experimental group in the post strategic listening skills due to (high-low) self-regulation skills?

\section{Methodology}

\subsection{Participants}

A total of (89) out of (4557) regular female $2^{\text {nd }}$ level students studying English for Academic purposes (EUSE2 Book) randomly selected during the second semester of the academic year (1438-1439) at the first year at X University. Simple random sampling techniques were used to select the students. The sample consisted of two groups; the control group comprised (43) students and the experimental group comprised (46) students. The students' ages range from 18 to 23 years of age.

\subsection{Instruments}

5.2.1 List of Strategic Listening Skills:

To prepare the list, the researcher reviewed some studies that conducted to measure strategic listening (Amin, Amin \& Aly, 2011; Schwartz, 1998), critical listening (e.g. Bohlken, 2000), metacognitive awareness (e.g. An \& Shi, 2013; Mokhtari \& Reichard, 2002; Schraw \& Dennison, 1994) as well as comprehension skills (e.g. An \& Shi, 2013), and find the similarities between them. After preparing a list of twenty eight skills, the list was expertly reviewed by EFL professors and teachers to measure the face validity.

5.2.2 Strategic Listening Skills Test (RCST):

The strategic listening skills test consisted of (46 items) was prepared by the researcher. The duration of the test was around 60 minutes, which means that students were given one minute to answer each item with fourteen minutes being distributed between the listening tracks. To ensure the validity of the SLST, a panel of EFL teachers and professors were consulted. They were asked about the appropriateness of each question to the (REAP2) students, the relevance of each question to the skill, and the clarity of each question linguistically. The Pearson correlation coefficient of each level scores with the total score were rather high and significant, $\mathrm{p}<0.01$. The reliability of the test was calculated (Cronbach's Alpha $=0.872)$. The test difficulty coefficients ranged from $(0.34$ to 0.83$)$, and the discrimination coefficients ranged from $(0.33$ to 0.89$)$.

5.2.3 The Self-Regulation Scale (SRS):

The current study adopted the Arabic version scale from (Author, 2013). It is 5-point Likert-scale instrument ranged from (very high to very low) measuring students self-regulation and it is conducted on university students. A checklist was presented to the reviewers in order to get their suggestions concerning the following criteria: a) the appropriateness of the statements for self-regulation, and b) the belonging of the statements to the dimensions. Appropriate statements were drawn from and added to this scale and restated and reformed to suit the needs of this research. The scale validity was verified, and the reliability of the scale was calculated using Cronbach's Alpha; it was (.920) suggesting that the scale was reliable.

\subsection{Listening Materials}

The teaching materials which are the listening tracks of English for Academic Purposes (EUSE2) book from unit 2 to 6 were prepared by the researcher and consisted of an instructor's guide and students' guide.

To verify the validity of the material, lesson plans for each unit were prepared and revised by the specialist in the fields of curricula and teaching methods.

\subsection{Procedure}

The researcher reviewed the literature connected with self-questioning strategy, strategic listening and selfregulation and used the English course material prescribed for regular $2^{\text {nd }}$ level students who studying English for Academic Purposes (EUSE2) as a basis for selecting the listening tracks. The list of strategic listening skills were 
prepared and its validity were verified. The content was designed based on self-questioning strategy. The researcher designed the strategic listening skills test and adapted the self-regulation scale, and their reliability and validity were verified.

The researcher explained to the instructors the research objective and how to conduct the pre- and the posttests. Then, the pre-test and pre-application of the scale was administered to both experimental and control groups. After that, the instructional units was presented to the experimental group through self-questioning strategy, and to the control group through the traditional way of teaching. The teaching of the five units in both the experimental and control groups lasted 8 weeks. Finally, the post-tests and the post-application of the scale were administered to the both groups.

\section{Results}

To test the first hypothesis; "There are no statistically significant differences at $(\alpha \leq 0.05)$ between the mean scores of the study groups in the post strategic listening skills (planning- organizing- monitoring- inferencing and analysing- evaluating)", Table 1 contains the mean scores and standard deviations of the control and experimental groups in the post-tests.

Table 1 Descriptive Statistics for Post Strategic Listening Main Skills Tests

\begin{tabular}{|c|c|c|c|c|c|}
\hline & Group & $\mathrm{N}$ & Mean & Std. Deviation & Std. Error Mean \\
\hline \multirow[t]{2}{*}{ Planning } & Control & 43 & 1.0465 & .53245 & .08120 \\
\hline & Experimental & 46 & 1.6087 & .53658 & .07912 \\
\hline \multirow[t]{2}{*}{ Organizing } & Control & 43 & 7.9535 & 3.28020 & .50023 \\
\hline & Experimental & 46 & 13.1739 & 3.36191 & .49569 \\
\hline \multirow[t]{2}{*}{ Monitoring } & Control & 43 & 7.5814 & 2.21717 & .33812 \\
\hline & Experimental & 46 & 10.8261 & 2.02544 & .29864 \\
\hline \multirow[t]{2}{*}{ Inferencing and Analyzing } & Control & 43 & 3.9302 & 1.51807 & .23150 \\
\hline & Experimental & 46 & 6.2391 & 1.28556 & .18955 \\
\hline \multirow[t]{2}{*}{ Evaluating } & Control & 43 & 1.1163 & .87856 & .13398 \\
\hline & Experimental & 46 & 2.7174 & 1.00362 & .14798 \\
\hline
\end{tabular}

As shown in Table 1, the experimental group performance in strategic listening main skills had a superiority over the control group in all main skills.

To test whether the differences were statistically significant between the two groups, Multivariate Analysis of Covariance (MANCOVA) was conducted. The pre-test scores were used as the covariate variable.

Table 2 Multivariate Test for the Covariate of Strategic Listening skills Test

\begin{tabular}{lllllll}
\hline Effect & & Value & F & Hypothesis df & Error df & Sig. \\
\hline Intercept & Pillai's Trace & .513 & $16.447^{\mathrm{a}}$ & 5.000 & 78.000 & .000 \\
& Wilks' Lambda & .487 & $16.447^{\mathrm{a}}$ & 5.000 & 78.000 & .000 \\
& Hotelling's Trace & 1.054 & $16.447^{\mathrm{a}}$ & 5.000 & 78.000 & .000 \\
& Roy's Largest Root & 1.054 & $16.447^{\mathrm{a}}$ & 5.000 & 78.000 & .000 \\
Group & Pillai's Trace & .523 & $17.127^{\mathrm{a}}$ & 5.000 & 78.000 & .000 \\
& Wilks' Lambda & .477 & $17.127^{\mathrm{a}}$ & 5.000 & 78.000 & .000 \\
& Hotelling's Trace & 1.098 & $17.127^{\mathrm{a}}$ & 5.000 & 78.000 & .000 \\
& Roy's Largest Root & 1.098 & $17.127^{\mathrm{a}}$ & 5.000 & 78.000 & .000 \\
\hline
\end{tabular}

The results of MANCOVA in Table 2 revealed a significant multivariate test for the covariate of SLST, Pillai's Trace statistic $=.523, \mathrm{~F}=17.127, \mathrm{p}=.000$, Wilks' Lambda statistic $=.477, \mathrm{~F}=17.127, \mathrm{p}=.000$, Hotelling's Trace statistic $=1.098, \mathrm{~F}=17.127, \mathrm{p}=.000$ and Roy's Largest Root statistic $=1.098, \mathrm{~F}=17.127, \mathrm{p}=.000$, which indicated that there were significant differences between the experimental group and the control group. 
Table 3 MANCOVA Results of the Pre and Post Strategic Listening Skills Test

\begin{tabular}{|c|c|c|c|c|c|c|c|}
\hline Source & Dependent Variable & $\begin{array}{ll}\text { Type III } \\
\text { Sum }\end{array}$ & df & $\begin{array}{l}\text { Mean } \\
\text { Square }\end{array}$ & $\mathrm{F}$ & Sig. & $\begin{array}{l}\text { Partial } \\
\text { Eta } \\
\text { Squared }\end{array}$ \\
\hline \multirow[t]{5}{*}{ Corrected Model } & Planning & $8.566^{\mathrm{a}}$ & 6 & 1.428 & 5.020 & .000 & .269 \\
\hline & Organizing & $876.964^{\mathrm{b}}$ & 6 & 146.161 & 17.389 & .000 & .560 \\
\hline & Monitoring & $315.689^{c}$ & 6 & 52.615 & 13.946 & .000 & .505 \\
\hline & Inferencing and Analyzing & $121.412^{\mathrm{d}}$ & 6 & 20.235 & 9.863 & .000 & .419 \\
\hline & Evaluating & $64.395^{\mathrm{e}}$ & 6 & 10.733 & 12.515 & .000 & .478 \\
\hline \multirow[t]{5}{*}{ Intercept } & Planning & 2.354 & 1 & 2.354 & 8.275 & .005 & .092 \\
\hline & Organizing & 155.236 & 1 & 155.236 & 18.469 & .000 & .184 \\
\hline & Monitoring & 180.598 & 1 & 180.598 & 47.869 & .000 & .369 \\
\hline & Inferencing and Analyzing & 115.071 & 1 & 115.071 & 56.089 & .000 & .406 \\
\hline & Evaluating & 3.436 & 1 & 3.436 & 4.007 & .049 & .047 \\
\hline \multirow[t]{5}{*}{ Group } & Planning & 3.700 & 1 & 3.700 & 13.010 & .001 & .137 \\
\hline & Organizing & 335.139 & 1 & 335.139 & 39.872 & .000 & .327 \\
\hline & Monitoring & 145.870 & 1 & 145.870 & 38.664 & .000 & .320 \\
\hline & Inferencing and Analyzing & 90.932 & 1 & 90.932 & 44.323 & .000 & .351 \\
\hline & Evaluating & 31.149 & 1 & 31.149 & 36.321 & .000 & .307 \\
\hline \multirow[t]{5}{*}{ Error } & Planning & 23.322 & 82 & .284 & & & \\
\hline & Organizing & 689.238 & 82 & 8.405 & & & \\
\hline & Monitoring & 309.367 & 82 & 3.773 & & & \\
\hline & Inferencing and Analyzing & 168.229 & 82 & 2.052 & & & \\
\hline & Evaluating & 70.324 & 82 & .858 & & & \\
\hline \multirow[t]{5}{*}{ Total } & Planning & 191.000 & 89 & & & & \\
\hline & Organizing & 11664.000 & 89 & & & & \\
\hline & Monitoring & 8254.000 & 89 & & & & \\
\hline & Inferencing and Analyzing & 2626.000 & 89 & & & & \\
\hline & Evaluating & 471.000 & 89 & & & & \\
\hline \multirow[t]{5}{*}{ Corrected Total } & Planning & 31.888 & 88 & & & & \\
\hline & Organizing & 1566.202 & 88 & & & & \\
\hline & Monitoring & 625.056 & 88 & & & & \\
\hline & Inferencing and Analyzing & 289.640 & 88 & & & & \\
\hline & Evaluating & 134.719 & 88 & & & & \\
\hline
\end{tabular}

Table 3 shows the results of MANCOVA which revealed that there was a statistically significant difference between the two groups in strategic listening post-test in all main skills: planning $(\mathrm{F}=13.010, \mathrm{p}=.001)$, organizing $(\mathrm{F}=39.872, \mathrm{p}=.000)$, monitoring $(\mathrm{F}=38.664, \mathrm{p}=.000)$, inferencing and analyzing $(\mathrm{F}=44.323, \mathrm{p}=.000)$, and evaluating $(\mathrm{F}=36.321, \mathrm{p}=.000)$, in favor of the experimental group. Consequently, using self-questioning strategy improved students' strategic listening comparing to the traditional teaching method. Therefore, the null hypothesis was rejected and the alternative one was accepted which is as follows: "There are statistically significant differences at $(\alpha \leq 0.05)$ between the mean scores of the study groups in the post strategic listening skills (planningorganizing- monitoring- inferencing and analyzing- evaluating) to the favor of the experimental group".

The effect size of self-questioning strategy was medium for planning $\left(\eta^{2}=.137\right)$, and large for organizing $\left(\eta^{2}=.327\right)$, monitoring $\left(\eta^{2}=.320\right)$, inferencing and analyzing $\left(\eta^{2}=.351\right)$, and evaluating $\left(\eta^{2}=: .307\right)$, which indicated that $13.7 \%, 32.7 \%, 32 \%, 35.1 \%$ and $30.7 \%$ of the variance of experimental group scores in planning, organizing, monitoring, inferencing and analyzing and evaluating respectively were due the use of self-questioning strategy.

To test the second hypothesis; "There are no statistically significant differences at $(\alpha \leq 0.05)$ between the mean scores of the study groups in the post self-regulation skills (goal setting and planning- organizing and transformingself-monitoring- self-evaluation)", Table 4 contains the mean scores and standard deviations of the control and experimental groups in the post-application. 
Table 4 Descriptive Statistics for Post Self-Regulation Main Skills Scale

\begin{tabular}{lllll}
\hline & Group & Mean & Std. Deviation & $\mathrm{N}$ \\
\hline Goal setting and Planning & Control & 3.5847 & .49371 & 43 \\
Organizing and Transforming & Experimental & 3.5932 & .55775 & 46 \\
\multirow{2}{*}{ Self-monitoring } & Control & 3.5465 & .65498 & 43 \\
& Experimental & 3.4783 & .68908 & 46 \\
Self-evaluation & Control & 3.7176 & .56155 & 43 \\
& Experimental & 3.6770 & .53658 & 46 \\
& Control & 3.8372 & .64008 & 43 \\
\hline
\end{tabular}

As displayed in Table 4, the self-regulation of the experimental group had a superiority over the control group in Goal setting and Planning, and Self-evaluation skills, whereas in Organizing and Transforming, and Selfmonitoring, the control group had a superiority over the experimental group.

To test whether the difference was statistically significant between the two groups, Multivariate Analysis of Covariance (MANCOVA) was conducted. The pre-application scores were used as the covariate variable.

Table 5 Multivariate Test for the Covariate of Self-Regulation skills Scale

\begin{tabular}{lllllll}
\hline Effect & & Value & $\mathrm{F}$ & Hypothesis df & Error df & Sig. \\
\hline Intercept & Pillai's Trace & .356 & $11.056^{\mathrm{a}}$ & 4.000 & 80.000 & .000 \\
& Wilks' Lambda & .644 & $11.056^{\mathrm{a}}$ & 4.000 & 80.000 & .000 \\
& Hotelling's Trace & .553 & $11.056^{\mathrm{a}}$ & 4.000 & 80.000 & .000 \\
& Roy's Largest Root & .553 & $11.056^{\mathrm{a}}$ & 4.000 & 80.000 & .000 \\
Group & Pillai's Trace & .032 & $.651^{\mathrm{a}}$ & 4.000 & 80.000 & .628 \\
& Wilks' Lambda & .968 & $.651^{\mathrm{a}}$ & 4.000 & 80.000 & .628 \\
& Hotelling's Trace & .033 & $.651^{\mathrm{a}}$ & 4.000 & 80.000 & .628 \\
& Roy's Largest Root & .033 & $.651^{\mathrm{a}}$ & 4.000 & 80.000 & .628 \\
\hline
\end{tabular}

The results from the MANCOVA in Table 5 revealed that multivariate test for the covariate of SRS is not significant, Pillai's Trace statistic $=.032, \mathrm{~F}=.651, \mathrm{p}=.628$, Wilks' Lambda statistic $=.968, \mathrm{~F}=.651, \mathrm{p}=.628$, Hotelling's Trace statistic $=.033, \mathrm{~F}=.651, \mathrm{p}=.628$ and Roy's Largest Root statistic $=.033, \mathrm{~F}=.651, \mathrm{p}=.628$, which indicated that the differences between the experimental group and the control group were not significant. Consequently, using self-questioning strategy did not improve students' self-regulation. Therefore, the null hypothesis was accepted.

To test the third hypothesis "There is no statistically significant difference at $(\alpha \leq 0.05)$ between the mean scores of the experimental group in the post strategic listening skills due to (high-low) self-regulation skills"; Ttest for independent samples was used. The mean scores and standard deviations of the post test administered to both groups (high-low) self-regulation skills were calculated in the following table.

Table 6 Descriptive Statistics for SLS Post-Test

\begin{tabular}{llllll}
\hline & Group & $\mathrm{N}$ & Mean & Std. Deviation & Std. Error Mean \\
\hline \multirow{2}{*}{ Test } & High & 23 & 36.1739 & 4.36569 & .91031 \\
& Low & 23 & 32.9565 & 7.25182 & 1.51211 \\
\hline
\end{tabular}

As displayed in Table 6, the mean score of the high self-regulation group in strategic listening skills test was $(M=36.1739)$ and for the low self-regulation group in the same test was $(M=32.9565)$ in the post-test. This table indicated that the high group outperformed the low group in the post application of the SLST. As indicated by this result, there was a difference between the high and low self-regulation groups performance on the post SLST. To find out whether the difference between the two groups was statistically significant, an independent samples t-test was run. The results were presented in Table 7.

Table 7 The Independent Samples t-test for the $3^{\text {rd }}$ Hypothesis

\begin{tabular}{llllll} 
& \multicolumn{2}{l}{ Levene's Test for Equality of Variances } & \multicolumn{3}{c}{ t-test for Equality of Means } \\
& $\mathrm{F}$ & Sig. & $\mathrm{t}$ & $\mathrm{df}$ & Sig. \\
Post-Test & 4.893 & .032 & 1.823 & 44 & .075 \\
\hline
\end{tabular}

The result of the independent samples T-test indicated that there was no significant difference between the two groups regarding their mean scores in the post SLST $(\mathrm{p}=0.075)$. Therefore, the null hypothesis was accepted.

\section{Discussion}

Depending on the results of the first hypothesis, it can be concluded that there are statistically significant differences at $(\alpha \leq 0.05)$ between the mean scores of the study groups in the post strategic listening skills (planningorganizing- monitoring- inferencing and analyzing- evaluating) in favor of the experimental group. It showed that using the self-questioning strategy before, during and after listening had significantly positive impact on the strategic listening. The main skills in general had a superiority over the control group, and that was clear when the 
experimental group's post-test scores were compared to the control group's post-test scores. In fact, this strategy helped the students to develop their planning organizing, monitoring, inferencing and analyzing and evaluating skills. The SQS was probably effective for helping students learn to generate their own questions, which may ultimately help them listen more independently and strategically, become active listeners, and engage with the audible text. Findings from this study support assertion made by Coskun, (2010), Lin \&Gan (2014), Nosratinia, Ghavidel and Zaker (2015), and Tabeei et al. (2013) in that metacognitive strategies had a positive effect on students' listening comprehension. Listening and reading both are receptive skills and the strategies used in reading are the same strategies in listening (Gear, 2008). The results of the current study support previous findings that SQS improve reading comprehension such as Afzali (2011), Joseph, Alber-Morgan, Cullen \& Rouse(2016), Rouse (2014), and Thomas (2002).

As revealed in the results of the second hypothesis, it can be concluded that there are no statistically significant differences at $(\alpha \leq 0.05)$ between the mean scores of the study groups in the post self-regulation skills (goal setting and planning- organizing and transforming- self-monitoring- self-evaluation). It indicated that using SQS in teaching was not effective in developing students' self-regulation. Although goal setting and planning skills, and self-evaluation skills proved of little value in increasing students' self-regulation when the experimental group's post-application scores were compared with the control group, the results from MANCOVA test was not significant. This means that the traditional method suited the first-year regular female students at Taif University. Teaching SQS over such a short period of time proved no value in increasing the students' self-regulation. The main reason behind this finding was the amount of time the researcher spent in teaching this strategy. Selfregulation skills might need more emphasis. Students should spend more time practicing this strategy. In addition, it is also beneficial for students needing extra support to receive guided practice and independent practice of SQS and self-regulation skills. This finding did not agree with the finding of Li (2017) and Nash-Ditzel (2010). NashDitzel's study (2010) showed that the metacognitive reading strategies can improve self-regulation. In addition, Li (2017) in his study revealed that some cognitive, metacognitive and motivational studies were effective in fostering self-regulation. This contradiction may be due to the different samples, educational context, students' proficiency level of English language, and for the short of time devoted for teaching the experimental group.

According to the results of the third hypothesis, it can be concluded that there is no statistically significant difference at $(\alpha \leq 0.05)$ between the mean scores of the experimental group in the post strategic listening skills due to (high-low) self-regulation skills. Regarding this result, the high and low level self-regulation students were equal in the strategic listening skills test. This finding contrasts partially with the findings of Fatemi, Alishahi, Khorasani\&Seifi (2014), and Zimmerman (2002). Fatemi, Alishahi, Khorasani\&Seifi's study (2014) showed that high level self-regulated learners have achieved high listening scores. Zimmerman (2002) stated that higher level self-regulated learners can find an appropriate solution during a task in a purposeful manner. This disagreement could be understandable because of the different samples, educational context and students' level of self-regulation. Besides, this result could be related to the fact that student in our schools are not aware of using self-regulation skills in their learning, Instead, they concentrate on memorization as a preferable way of learning.

\section{Conclusion}

Finally, it worth mentioned that this study provided clear evidence of the effectiveness of using the SQS in developing the five levels of strategic listening. In the first place, the SQS developed the planning level, including developing the skills of prediction and connection between the existing information and the previous knowledge. Additionally, the SQS helped the students to organize the information in the audible text by taking notes, classifying and paraphrasing the information. Their ability to monitor the audible text as well as their ability to evaluate it increased. Also, the SQS helped students to inference and analyze the text. On the contrary, the SQS did not develop students' self-regulation, and it showed no differences in students' performance in the strategic listening skills test due to the differences in their self-regulation skills levels.

Based on the study results, the most important recommendations have been to integrate strategic listening and self-regulation skills in the curriculum in order to help students to be responsible for their own learning of listening comprehension by Curriculum designers of the English language, and to conduct professional development programs (PDPs) for EFL teachers about the importance of using effective methods promote students' selfregulation and strategic listening and to focus more on using the elf-questioning strategy as a new strategic listening instruction.

\section{References}

Abbasian, G. R., \& Hartoonian, A. (2014). Using self-regulated learning strategies in enhancing language proficiency with a focus on reading comprehension. English Language Teaching, 7(6), 160-167. doi:10.5539/elt.v7n6p160.

Afzali, K. (2012). The impact of instructing self-questioning in reading literary texts. International Journal of Linguistics, 4(2), 536-550. doi:10.5296/ijl.v4i2.1862. 
Aguilera, G., Illesca, C., Montecinos, C., Sandoval, V., Navarro, C., \& Whipple, K. (2016). Metacognitive listening strategies: Exploring the effects of implicit metacognitive instruction on intermediate second/foreign English language learners at Universidad de Chile. Faculty of Philosophy and Humanities, Chile University.

Alasmari, A. (2016). Continuous professional development of English language teachers: Perception and practices. Advances in Language and Literary Studies, 7(3), 117-124. doi:10.7575/aiac.alls.v.7n.3p.117.

Alhayajnah, S. F., Altall, S. A. (2017). The effectiveness of self-questioning and POSSE strategies in the development of reading comprehension and meta-reading comprehension. IUG Journal of Educational and Psychology Sciences, 25(4), 446-471. (Arabic).

Alsoud, A. K. (2016). The effect of self-questioning strategy on seventh grader female student's reading comprehension skills and attitudes towards reading in Jordan (Master thesis). Alhashimiah University, Jordan. (Arabic).

Author, (2013). (details removed for peer review).

Amin, I. A. R., Amin, M. M., \& Aly, M. A. S. (2011). A Correlation Study between EFL Strategic Listening and Listening Comprehension Skills among Secondary School Students. https://eric.ed.gov/?id=ED527448

An, X., \& Shi, Z. (2013). Does metacognitive instruction improve listening comprehension?. Theory and Practice in Language Studies, 3(4), 632-636. doi:10.4304/tpls.3.4.632-636.

Bembenutty, H. (Ed.). (2011). Introduction: Self-regulation of learning in postsecondary education. In Selfregulated learning (pp. 3-8). Wiley Periodicals, Inc., A Wiley Company.

Bohlken, B. (2000). Training citizens in a democratic society To listen critically. https://eric.ed.gov/?id=ED438584

Borkowski, J. G., \& Thorpe, P. K. (1994). Self-regulation and motivation: A life-span perspective on underachievement.Abstract retrieved from http://psycnet.apa.org/record/1994-97658-002

Cetin, B. (2015). Academic motivation and self-regulated learning in predicting academic achievement in college. Journal of International Education Research, 11(2), 95-106.

Coskun, A. (2010). The effect of metacognitive strategy training on the listening performance of beginner students. Novitas-ROYAL (Research on Youth and Language), 4(1), 35-50.

Cubukcu, F. (2009). Learner autonomy, self-regulation and metacognition. International Electronic Journal of Elementary Education, 2(1), 53-64.

Ebadi, S., \& Shakoorzadeh, R. (2015). Investigation of academic procrastination prevalence and its relationship with academic self-regulation and achievement motivation among high-school students in Tehran City. International Education Studies, 8(10), 193-199. doi:10.5539/ies.v8n10p193.

Eissa, M. A. (2015). The effectiveness of a self-regulated learning-based training program on improving cognitive and metacognitive EFL reading comprehension of 9th graders with reading disabilities. International Journal of Psycho-Educational Sciences, 4(3), 49-59.

El-Sakka, S. M. F. (2016). Self-regulated strategy instruction for developing speaking proficiency and reducing speaking anxiety of Egyptian university students. English Language Teaching, 9(12), 22-33. doi:10.5539/elt.v9n12p22.

Erdogan, T. (2017). The investigation of the relationship between self-regulation and language learning strategies. The Eurasian Proceedings of Education and Social Sciences, 7(1), 38-43.

Eslahkonha, F., \& Mall-Amiri, B. (2014). The correlation between English language listening comprehension ability and listening strategy use among Iranian TEFL junior university students. International Journal of Language Learning and Applied Linguistics World (IJLLALW), 7(2), 190-203.

Fatemi, M. A., Alishahi, M., Khorasani, M. N., \& Seifi, M. (2014). The relationship between EFL learners' selfregulation and their listening comprehension. Advances in Language and Literary Studies, 5(4), 198-201. doi:10.7575/aiac.alls.v.5n.4p.198.

Fermín, T., \& María, C. (2010). Self-Regulated Learning: Current and Future Directions. Electronic Journal of Research in Educational Psychology, 2(1), 1-34.

Freahat, N. M., \& Smadi, O. M. (2014). Lower-order and higher-order reading questions in secondary and university level EFL textbooks in Jordan. Theory and Practice in Language Studies, 4(9), 1804-1813. doi:10.4304/tpls.4.9.1804-1813.

Gear, A. (2008). Nonfiction reading power: Teaching students how to think while they read all kinds of information. Pembroke Publishers Limited.

Gilakjani, A. P., \& Sabouri, N. B. (2016). Learners' listening comprehension difficulties in English language learning: A Literature review. English Language Teaching, 9(6), 123-133. doi: 10.5539/elt.v9n6p123.

Goh, C. C. M., \& Kaur, K. (2013). Insights into young learners' metacognitive awareness about listening. The European of Applied Linguistics and TEFL, 2(1), 5-26.

Hatami, A. (2015). The effect of collaborative learning and self-assessment on self-regulation. Educational Research and Reviews, 10(15), 2164-2167.doi: 10.5897/ERR2015.2349. 
He, X. (2016). Non-English majors' listening teaching based on lexical chunks theory and schema theory. English Language Teaching, 9(2), 142-147. doi:10.5539/elt.v9n2p142.

Huy, L. H. (2015). An investigation into listening strategies of EFL students. Asian Journal of Educational Research, 3(4), 21-34.

Janssen, T. (2002). Instruction in self-questioning as a literary reading strategy: An exploration of empirical research. L1-Educational Studies in Language and Literature, 2(2), 95-120.

Joseph, L. M., Alber-Morgan, S., Cullen, J., \& Rouse, C. (2016). The effects of self-questioning on reading comprehension: A literature review. Reading \& Writing Quarterly, 32(2), 152-173. doi: 10.1080/10573569.2014.891449.

Kassem, H. M. (2015). The relationship between listening strategies used by Egyptian EFL college sophomores and their listening comprehension and self-efficacy. English Language Teaching, 8(2), 153-169. doi:10.5539/elt.v8n2p153.

Kaya, T. (2017). A Follow-up Study on Listening Strategy Use and Self-Efficacy in Relation to Listening Proficiency in EFL. The Economic Review of Toyo University, 42(2), 155-166.

Khusainova, R. M., \& Ivutina, H. P. (2016). Styles of self-regulation of learning activities of university students. International Journal of Environmental and Science Education, 11(13), 5980-5992.

Kramarski, B., \& Dudai, V. (2009). Group-metacognitive support for online inquiry in mathematics with differential self-questioning. Journal of Educational Computing Research,40(4), 377-404. doi: 10.2190/EC.40.4.a.

Leana-Tascilar, M. Z. (2016). The relationships between self-regulated learning skills, causal attributions and academic success of trainee teachers preparing to teach gifted students. Educational Research and Reviews, 11(13), 1217-1227.doi: 10.5897/ERR2016.2818.

Li, Y. (2017). Exploring Self-Regulated Learning (SRL) and Listening Strategy Instruction in A Chinese L2 Classroom (Doctoral dissertation). The University of San Francisco.

Lichtinger, E., \& Kaplan, A. (2011). Purpose of engagement in academic self-regulation. New Directions for Teaching and Learning, 2011(126), 9-19.

Lin, C. Y., \& Gan, X. N. (2014). Taiwanese college students' use of English listening strategies and self-regulated learning. International Journal on Studies in English Language and Literature, 2 (5), 57-65.

Livingston, $\quad$ J. $\quad$ A. $\quad$ (2003). Metacognition: An https://eric.ed.gov/?q=Metacognition\%3a+An+overview.\%e2\%80\%8f\&id=ED474273.

Lubliner, S. (2004). Help for struggling upper-grade elementary readers. The Reading Teacher, 57(5), 430-438.

Maralani, F. M. (2016). The mediation role of intrinsic and extrinsic motivation in the relationship between creative educational environment and metacognitive self-regulation. Journal of Education and Learning, 5(3), 272-277. doi:10.5539/jel.v5n3p272.

Martirossian, A., \& Hartoonian, A. (2015). Lowering foreign language anxiety through self-regulated learning strategy use. English Language Teaching, 8(12), 209-222. doi:10.5539/elt.v8n12p209.

McCaslin, M., \& Hickey, D. T. (2001). Educational psychology, social constructivism, and educational practice: A case of emergent identity. Educational Psychologist, 36(2), 133-140.

Miciano, R. Z. (2002). Self-questioning and prose comprehension: A sample case of ESL reading. Asia Pacific Education Review, 3(2), 210-216.

Miedijensky, S., \& Lichtinger, E. (2016). Seminar for Master's thesis projects: Promoting students' selfregulation. International Journal of Higher Education, 5(4), 13-26. doi:10.5430/ijhe.v5n4p13.

Mokhtari, K., \& Reichard, C. A. (2002). Assessing students' metacognitive awareness of reading strategies. Journal of Educational Psychology, 94(2), 249-259. doi: 10.1037//0022-0663.94.2.249.

Montroy, J. J., Bowles, R. P., Skibbe, L. E., \& Foster, T. D. (2014). Social skills and problem behaviors as mediators of the relationship between behavioral self-regulation and academic achievement. Early Childhood Research Quarterly, 29(3), 298-309.

Movahed, R. (2014). The effect of metacognitive strategy instruction on listening performance, metaconitive awareness and listening anxiety of beginner Iranian EFL students. International Journal of English Linguistics, 4(2), 88-99.doi:10.5539/ijel.v4n2p88.

Na, H. J., \& Yang, S. (2009). Effects of listening to music on auditory hallucination and psychiatric symptoms in people with schizophrenia. Journal of Korean Academy of Nursing, 39(1), 62-71.

Nash-Ditzel, S. (2010). Metacognitive reading strategies can improve self-regulation. Journal of College Reading and Learning, 40(2), 45-63.

Nejad, S. P. (2015). The effect of metacognitive strategy instruction on listening performance pre-Intermediate Iranian EFL learners. Indian Journal of Fundamental and Applied Life Sciences, 5(3), 1474-1480.

Nosratinia, M., Ghavidel, S., \& Zaker, A. (2015). Teaching metacognitive strategies through Anderson's model: does it affect EFL learners' listening comprehension?. Theory and Practice in Language Studies, 5(6), 12331243. doi: http://dx.doi.org/10.17507/tpls.0506.16. 
Oruç, A., \& Arslan, A. (2016). The impact of self-regulated learning on reading comprehension and attitude towards Turkish course and metacognitive thinking. Educational Research and Reviews, 11(8), 523-529. doi: 10.5897/ERR2016.2692.

O'Shea, D. J., \& Obiakor, F. E. (2008). Culturally responsive literacy instruction. Corwin Press.

Pan, Y. C. (2015). Relationships between strategy use, listening proficiency level, task type, and scores in an L2 listening test. Canadian Journal of Applied Linguistics/Revue canadienne de linguistique appliquée, 18(2), 45-77.

Piamsai, C. (2014). An investigation of the use of listening strategies and listening performance of proficient and non-proficient language learners. PASAA: Journal of Language Teaching and Learning in Thailand, 47, 147180.

Pintrich, P. R. (Ed.). (2000). The role of goal orientation in self-regulated learning. In Handbook of selfregulation (pp. 451-502). Academic Press.

Punhagui, G. C., \& Souza, N. A. (2013). Self-regulation in the learning process: Actions through self-assessment activities with Brazilian students. International Education Studies, 6(10), 47-62. doi:10.5539/ies.v6n10p47.

Richards, J. C. (2008). Teaching listening and speaking. Cambridge: Cambridge University Press.

Rouse, C. A. (2014). The Effects of a Self-Questioning Strategy on the Comprehension of Expository Passages by Elementary Students Who Struggle With Rwading (Doctoral dissertation). The Ohio State University.

Rouse, C. A., Alber-Morgan, S. R., Cullen, J. M., \& Sawyer, M. (2014). Using prompt fading to teach selfquestioning to fifth graders with LD: Effects on reading comprehension. Learning Disabilities Research \& Practice, 29(3), 117-125.

Schraw, G., \& Dennison, R. S. (1994). Assessing metacognitive awareness. Contemporary Educational Psychology, 19(4), 460-475.

Schunk, D. H., \& Zimmerman, B. J. (2007). Influencing children's self-efficacy and self-regulation of reading and writing through modeling. Reading \& Writing Quarterly, 23(1), 7-25. doi: 10.1080/10573560600837578.

Schwartz, A. M. (1998). Listening in a Foreign Language. https://eric.ed.gov/?id=ED433723

Shang, H. F., \& Chang-Chien, I. J. (2010). The effect of self-questioning strategy on EFL learners' reading comprehension development. International Journal of Learning, 17(2).

Steiner, H. H. (2016). The strategy project: promoting self-regulated learning through an authentic assignment. International Journal of Teaching and Learning in Higher Education, 28(2), 271-282.

Stiller, J., \& Dunbar, R. I. (2007). Perspective-taking and memory capacity predict social network size. Social Networks, 29(1), 93-104. doi:10.1016/j.socnet.2006.04.001.

Su, Y., Zheng, C., Liang, J. C., \& Tsai, C. C. (2018). Examining the relationship between English language learners' online self-regulation and their self-efficacy. Australasian Journal of Educational Technology, 34(3), 105121

Sunggingwati, D., \& Nguyen, H. T. M. (2013). Teachers' questioning in reading lessons: A case study in Indonesia. Electronic Journal of Foreign Language Teaching, 10(1), 80-95.

Tabeei, S. N., Tabrizi, A. R., \& Ahmadi, G. (2013). The effect of metacognitive strategies instruction on listening comprehension of Iranian EFL learners: Focusing on gender. International Journal of Language Learning and Applied Linguistics World, 4(4), 13-29.

Thomas, M. J. (2002). Self-questioning to improve comprehension (Master thesis). California State University San Marcos, USA.

Woolley, G. (2011). Reading comprehension: Assisting children with learning difficulties. Retrieved from https://books.google.com.sa/books?id=S9keqWMlu6wC\&printsec=frontcover\&dq=Woolley+2011\&hl=ar\& $\mathrm{sa}=\mathrm{X} \& \mathrm{ved}=0 \mathrm{ahUKEwi} \mathrm{v}-\mathrm{mBmPbaAhXBUBQKHVKEBgAQ6AEIJTAA \# v}=$ onepage $\& \mathrm{q} \& \mathrm{f}=$ false

Zanjani, B. A., \& Izadpanah, S. (2016). The impact of listening strategies on improving learners' listening skill in Iran. Journal of Language Teaching and Research, 7(6), 1089-1096. doi: http://dx.doi.org/10.17507/jltr.0706.04.

Zarrabi, F. (2016). The impact of listening strategy training on the meta-cognitive listening strategies awareness of different learner types. English Language Teaching, 9(5), 154-165.doi: 10.5539/elt.v9n5p154.

Zeng, Y. (2014). Investigating the effects of metacognitive instruction on Chinese EFL learners' listening performance. International Journal of Innovation in English Language Teaching and Research, 3(2), 139249.

Zhao, W. (2016). Academic English teaching for postgraduates based on self-regulated learning environment: A case study of academic reading course. English Language Teaching, 9(5), 214-224. doi: 10.5539/elt.v9n5p214.

Zimmerman, B. J. (1990). Self-regulated learning and academic achievement: An overview. Educational Psychologist, 25(1), 3-17.

Zimmerman, B. J. (2002). Becoming a self-regulated learner: An overview. Theory into practice, 41(2), 64-70.

Zimmerman, B. J. (2008). Investigating self-regulation and motivation: Historical background, methodological 
developments, and future prospects. American Educational Research Journal,45(1), 166-183. doi: $10.3102 / 0002831207312909$.

Zimmerman, B. J. (2013). From cognitive modeling to self-regulation: A social cognitive career path. Educational psychologist, 48(3), 135-147.

Zimmerman, B. J. (Ed.). (2000). Attaining self-regulation: A social cognitive perspective. In Handbook of selfregulation (pp. 13-39).

Zumbrunn, S., Tadlock, J., \& Roberts, E. D. (2011). Encouraging self-regulated learning in the classroom: A review of the literature. Metropolitan Educational Research Consortium (MERC), 1-28.

Maraam Alutaybi is an an English language instructor in English Language Centre at Taif University, Taif, Saudi Arabia. She has received her M.A. in curricula and methods of teaching English from Faculty of Education at Taif University, Taif, Saudi Arabia. She is a Cambridge certified teacher trainer. She has 5+ years of experience in the fields of education and ELT. Her research interests include TEFL, language strategies, and digital learning.

Hamad Alsowat is an associate professor of English language teaching. He works at Taif University and is currently the head of the Department of Curriculum and Educational Technology. He has PhD in English language teaching from Umm Al-Qura University. He has 20+ years of experience in the fields of education and ELT. He publishes a number of research in language anxiety, strategies of English language teaching and technology incorporation in language teaching. He works as an editorial member and reviewer for many international and local scientific journals. He has supervised and examined a number of Master's these and doctoral dissertations in Saudi Arabia. 